\title{
Response of Cucumber to Nitrogen and Potassium Fertilization in Makurdi, Southern Guinea Savanna of Nigeria
}

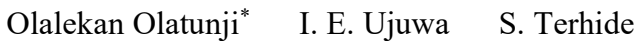 \\ Department of Soil Science, Federal University of Agriculture, Makurdi-Nigeria
}

\begin{abstract}
A field experiment was carried out at the Teaching and Research Farm of the University of Agriculture Makurdi, Benue State in the Southern Guinea Savanna zone of Nigeria during 2017 cropping season to evaluate the effect of varying rates of Nitrogen and Potassium on the growth and yield of Cucumber. Nitrogen $(50 \mathrm{Kg} \mathrm{N} / \mathrm{ha}, 100 \mathrm{Kg}$ $\mathrm{N} / \mathrm{ha}$ and $150 \mathrm{Kg} \mathrm{N} / \mathrm{ha}$ ), Potassium $\left(50 \mathrm{Kg} \mathrm{K} \mathrm{K}_{2} \mathrm{O} / \mathrm{ha}\right.$ and $\left.75 \mathrm{Kg} \mathrm{K}_{2} \mathrm{O} / \mathrm{ha}\right)$ were combined randomly with basal Phosphorous $\left(50 \mathrm{Kg} \mathrm{P}_{2} \mathrm{O}_{5} / \mathrm{ha}\right.$ ) to give seven treatment combinations. The experiment was laid out in a Randomized Complete Block Design (RCBD) and replicated three times. The crop data collected include number of leaves, leaf area and number of branches, vine length, vine diameter, fruit weight and yield. The result showed that application of Nitrogen and Potassium fertilizers at various rate significantly $(\mathrm{P}<0.05)$ increased the growth and yield of cucumber over the control. The highest rate of $150 \mathrm{KgN} / \mathrm{ha}+50 \mathrm{Kg} \mathrm{P}_{2} \mathrm{O}_{5} / \mathrm{ha}+50 \mathrm{Kg}$ $\mathrm{K}_{2} \mathrm{O} / \mathrm{ha}$ result to higher vegetative growth than fruit yield. The combination of $50 \mathrm{KgN} / \mathrm{ha}+50 \mathrm{Kg} \mathrm{P}_{2} \mathrm{O}_{5} / \mathrm{ha}+75$ $\mathrm{Kg} \mathrm{K}_{2} \mathrm{O} / \mathrm{ha}$ gave the highest yield and therefore considered optimal for cucumber production in the study area.
\end{abstract}

Keywords: Nitrogen and Potassium, Fertilization, Guinea Savanna, Cucumber

DOI: $10.7176 / \mathrm{JBAH} / 11-12-05$

Publication date:June $30^{\text {th }} 2021$

\section{Introduction}

Most soils in Benue State as a result of continuous cropping over time, have suffered nutrient depletion such that yields can only be attained through the judicious application of inorganic fertilizers. Farmers in this locality for a long time had relied on natural recycling process for fertility restoration but population growth has shortened the fallow periods and this has a negative effect on crop yield. Many studies of various crops have shown significant advantages of applying fertilizers (Akinrinde, 2006).

Cucumber (Cucumis sativus c.) is an important vegetable crop grown worldwide (Burkill, 1985). It is a warm season crop, which grows best at temperatures ranging between 24 and $29{ }^{\circ} \mathrm{C}$ in Nigeria. It is an ancient vegetable and one of the most important members of the Cucurbitaceae family (Thoa, 1998), that is cultivated for its fruit which is rich source of minerals and vitamins. The soils where cucumber is cultivated require moderate to high nutrient level so as to achieve high yields. Infertile soils result in bitter and misshapen fruits which are often rejected by consumers thereby.

The importance of fertilizer application to cucumber has been reported by (Kano et al., 2001; Moreno et al., 2003; Jass-Chaverria et al., 2005). In Nigeria, cucumber is a relatively recent addition to the diet. Apart from eating cucumber raw or in salad mixes, cucumber leaf juice has medicinal used. The leaf juice is emetic and is used to treat byspepsia in children (Messien, 1988). Not so much research has been conducted on cucumber, so there is paucity of literature on its fertilizer requirements in Nigeria and Benue State in particular.

Ekwu et al. (2000) reported that application of NPK (20:10:10) fertilizer at the rate of $150 \mathrm{~kg} \mathrm{~N} \mathrm{ha}^{-1}$ is used by farmers on cucumber in southern Nigeria. Fertilizer application is soil, site and crop specific therefore, this study was carried out to determine the effect of different levels of nitrogen and potassium in their various combinations on the growth and yield of cucumber in Makurdi southern Guinea savanna zone of Nigeria.

\section{Materials and Methods}

2.1 Location: The research work was conducted during the wet season of 2017 at the Teaching and Research Farm of the University Agriculture, Makurdi on Lat. $7^{\circ} 44^{\prime} \mathrm{N}$ Long. $8^{\circ} 37^{\prime} \mathrm{E}$ at an elevation of $97 \mathrm{~m}$ above sea level. The location falls within the southern guinea savanna agro-ecological zone of Nigeria. The soil of the site was locally classified as tropical ustropets using FAO-ISRIC, 1990 soil taxonomy.

\subsection{Design of experiment}

The study consists of seven (7) treatments combination of varying rates of nitrogen and potassium. Nitrogen $(50 \mathrm{~kg} \mathrm{~N} / \mathrm{ha}, 100 \mathrm{kgN} / \mathrm{ha}$ and $150 \mathrm{kgN} / \mathrm{ha})$, Potassium $\left(50 \mathrm{~kg} \mathrm{~K}_{2} \mathrm{O} / \mathrm{ha}\right.$ and $\left.75 \mathrm{kgK}_{2} \mathrm{O} / \mathrm{ha}\right)$ and phosphorus $\left(50 \mathrm{kgP}_{2} \mathrm{O}_{5} /\right.$ ha) applied as a basal treatment to all the plots. The experiment was laid out in a Randomized Complete Block Design (RCBD) and replicated three times. Each plot measured $3 \mathrm{~m} \times 4 \mathrm{~m}\left(12 \mathrm{~m}^{2}\right)$ with an alley of $1 \mathrm{~m}$ between blocks and $0.5 \mathrm{~m}$ between plots. The gross experimental plot was $637 \mathrm{~m}^{2}$. An improved variety of Ashley cucumber of $40-50$ days maturity was obtained from the National Agricultural Seed Council of Nigeria Abuja, Nigeria. 


\subsection{Land preparation}

The site use for the experiment was manually cleared and rigged, divided into blocks and plots. The planting of cucumber seeds was done in the month of August, 2017. The cucumber seeds were planted in rows spaced $25 \mathrm{~cm}$ apart and $50 \mathrm{~cm}$ within row to allow for trellising. Three cucumber seeds were planted per hole and later thinned down to two plants per stand at two weeks after planting.

\subsection{Cultural practices}

Weeding was done manually at intervals of 3 and 6 weeks after planting (WAP) to reduce competition of weeds. There were insect pest (cucumber beetle) and fungal disease (anthracaose) threat to the growth of cucumber plants during the trial, the crops were sprayed twice $4^{\text {th }}$ and $6^{\text {th }}$ week after planting with BEST (cypermethrin) and fungicide, benomyl (benlate) at the rate of 12 and $1.5 \mathrm{a} . \mathrm{c} \mathrm{kg} / \mathrm{ha}$ respectively in a knapsack sprayer to control the pest and disease attack. NPK fertilizer was applied to various plots according to treatment plan after two weeks after planting (2 WAP).

\subsection{Data collection and Analysis}

2.5.1 Soil: A composite sample was collected at the $0-15 \mathrm{~cm}$ depth from random points on the field before treatments application. The composite sample taken was air dried and sieved with a $2 \mathrm{~mm}$ sieve and was subjected to standard laboratory analysis as outlined by Udo et al. (2009).

2.5.2 Plant: Five plants were randomly tagged in each net plot from where leaf area, vine length, number of leaves, number of branches, fruit length, fruit diameter were taken. The cumulative yield from each net plot beginning from first harvest to last harvest was extrapolated to yield in tonnes per hectare. The growth parameters were assessed at 4, 6 and 8 weeks after planting. The crop data were subjected to analysis of variance (ANOVA) using Genstat Release 10.3 DE. FLSD was calculated at $\mathrm{P}<0.05$

\section{Results and Discussion}

3.1 Initial properties of soil:

Result of the physio-chemical analysis of the soil used for the experiment (Table 1) indicates that the soil is low in OM, N, P and exchangeable bases and CEC. This result indicates that the soil needs amendment which is in agreement with Agboola (1975) who reported that farmers in Africa require adequate soil amendment for good crop production as a result of low inherent soil fertility.

\subsection{Effect of treatment on Growth Cucumber}

Data obtained on the leaf area, number of leaves and vine length of cucumber (Tables 2 and 3) shows that fertilizer treatments application significantly $(\mathrm{P}<0.05)$ affected both growth parameters positively and differently at all the intervals the data were taken (4 WAP, 6 WAP, 8 WAP). The largest leaf area was obtained at 8 WAP from Treatment 3: $50 \mathrm{~kg} \mathrm{~N} / \mathrm{ha}+50 \mathrm{~kg} \mathrm{P}_{2} \mathrm{O}_{5} / \mathrm{ha}+75 \mathrm{~kg} \mathrm{~K} 2 \mathrm{O} / \mathrm{ha}\left(319.7 \mathrm{~cm}^{2}\right)$ the least value $\left(87.7 \mathrm{~cm}^{2}\right)$ was obtained from the control at $4 \mathrm{WAP}$. The highest number of leaves was obtained from Treatment 7: 150kg $\mathrm{N} / \mathrm{ha}+50 \mathrm{~kg} \mathrm{P}_{2} \mathrm{O}_{5} / \mathrm{ha}+75 \mathrm{~kg} \mathrm{~K} \mathrm{~K}_{2} \mathrm{O} / \mathrm{ha}(50.5)$ at $8 \mathrm{WAP}$, while the least was observed at $4 \mathrm{WAP}$ (7.67) from the control. The response of the vine length to the treatments show that Treatment 3: $50 \mathrm{~kg} \mathrm{~N} / \mathrm{ha}+50 \mathrm{~kg} \mathrm{P}_{2} \mathrm{O}_{5} / \mathrm{ha}$ $+75 \mathrm{~kg} \mathrm{~K} 2 \mathrm{O} /$ ha at $8 \mathrm{WAP}$ gave the longest vine length (147.3), the least vine length (9.23) was recorded at 4 WAP from the control. The cucumber plants that received $50 \mathrm{~kg} \mathrm{~N}, 50 \mathrm{~kg} \mathrm{P}_{2} \mathrm{O}_{5} ; 75 \mathrm{kgK}_{2} \mathrm{O}$ (Treatment 3) had the highest leaf area. This could be attributed to the fact that NPK fertilizer increased the nutrient availability to the root zone of the cucumber which may have been translocated to the leaf region, this favours the findings of Hamma et al. (2012), Olatunji, O (2017) their work indicated that production of cucumber can be enhanced by the application of manure. This is also consistent with the findings of Opara et al. (2011) who reported that various combined nutrient treated plots of poultry manure and NPK 15: 15: 15 significantly influenced vine length and leaf area than plots treated with single nutrient control. The result on vine length of cucumber followed similar trend with the leaf area. This could be as a result of higher nutrient content released and utilized by the plants at 8 WAP which induced longer vine length and larger leaf area. This fact is in harmony with the report of John et al. (2014) who indicated that fertilizer released essential elements which promoted high photosynthetic activities that enhanced growth and yield of most vegetables. Treatment 7: $150 \mathrm{~kg} \mathrm{~N} / \mathrm{ha}+50 \mathrm{~kg}$ $\mathrm{P}_{2} \mathrm{O}_{5} /$ ha $+75 \mathrm{~kg} \mathrm{~K} 2 \mathrm{O} /$ ha gave the highest number of leaves at $8 \mathrm{WAP}$, this is due to the release of nutrients at the later stage of growth as a result of excessive nutrients, this agrees with the work of Hector et al. (1993) who recommended that for effective treatment effects, a combination of both organic and inorganic fertilizer is necessary to achieve significant results.

\subsection{Effect of treatment on yield components of cucumber}

Observation on yield components (Table 3 ) shows that the fertilizer treatments significantly $(\mathrm{P}<0.05)$ improved the yield components more than the control. Treatment 6: $150 \mathrm{~kg} \mathrm{~N} / \mathrm{ha}+50 \mathrm{~kg}_{2} \mathrm{O}_{5} / \mathrm{ha}+50 \mathrm{~kg} \mathrm{~K}{ }_{2} \mathrm{O} / \mathrm{ha}$ gave the 
highest value $(20.80 \mathrm{~cm})$ of fruit girth Treatment 3: $50 \mathrm{~kg} \mathrm{~N} / \mathrm{ha}+50 \mathrm{~kg} \mathrm{P}_{2} \mathrm{O}_{5} / \mathrm{ha}+75 \mathrm{~kg} \mathrm{~K} 2 \mathrm{O} / \mathrm{ha}(20.07 \mathrm{~cm})$. Treatment 2: $50 \mathrm{~kg} \mathrm{~N} / \mathrm{ha}+50 \mathrm{~kg} \mathrm{P}_{2} \mathrm{O}_{5} / \mathrm{ha}+50 \mathrm{~kg} \mathrm{~K} 2 \mathrm{O} / \mathrm{ha}(19.92 \mathrm{~cm})$, the least value was obtained from the control. In terms of fruit length; Treatment 6: $150 \mathrm{~kg} \mathrm{~N} / \mathrm{ha}+50 \mathrm{~kg} \mathrm{P}_{2} \mathrm{O}_{5} / \mathrm{ha}+50 \mathrm{~kg} \mathrm{~K} 2 \mathrm{O} /$ ha produced the longest fruit length $(19.97 \mathrm{~cm})$ followed the longest fruit length $(19.97 \mathrm{~cm})$ is Treatment $4: 100 \mathrm{~kg} \mathrm{~N} / \mathrm{ha}+50 \mathrm{~kg} \mathrm{P}_{2} \mathrm{O}_{5} / \mathrm{ha}$ $+50 \mathrm{~kg} \mathrm{~K} 2 \mathrm{O} / \mathrm{ha}(19.33 \mathrm{~cm})$ and the least $(17.03 \mathrm{~cm})$ from control. For the overall fruit yield, Treatment 3: $50 \mathrm{~kg}$ $\mathrm{N} / \mathrm{ha}+50 \mathrm{~kg} \mathrm{P}_{2} \mathrm{O}_{5} / \mathrm{ha}+75 \mathrm{~kg} \mathrm{~K} \mathrm{~K}_{2} \mathrm{O} /$ ha produced the highest yield $(5.96 \mathrm{t} / \mathrm{ha})$, the least was obtained from Treatment 7: $150 \mathrm{~kg} \mathrm{~N} / \mathrm{ha}+50 \mathrm{~kg} \mathrm{P}_{2} \mathrm{O}_{5} / \mathrm{ha}+75 \mathrm{~kg} \mathrm{~K} \mathrm{~K}_{2} / \mathrm{ha}(2.91 \mathrm{t} / \mathrm{ha})$. The longest fruit was obtained from cucumber plants that received $150 \mathrm{~kg} \mathrm{~N} / \mathrm{ha}+50 \mathrm{~kg} \mathrm{P}_{2} \mathrm{O}_{5} / \mathrm{ha}+50 \mathrm{~kg} \mathrm{~K}_{2} \mathrm{O} / \mathrm{ha}$ and the shortest fruit length from the control, this result is similar to the findings of Musara and Chitamba, (2014) who indicated that there was a strong linear relationship between growth rate and fruit yield of cucumber sativa and manure application rates. This also corroborates the findings of Esawy et al., 2009 who reported that the combination of organic and inorganic fertilizer could increase plant growth, yield quality and soil fertility. The fruit circumference (girth) followed same trend with fruit length, this could be attributed to the fact that there is enhanced greater nutrient availability to plants. This is in consonance with the report of John et al. (2014) as earlier observed under growth parameters. The significant improvement in the fruit weight of cucumber is in agreement with the findings of Brady and Weil (2005) who stated that fertilizers can improve the soil nutrients and increase the root development that can positively lead to more uptakes of water and nutrients.

\section{Conclusion}

The effect of varying rates of Nitrogen and Potassium on cucumber was investigated in this study. It was found that various combinations positively affect both the growth and yield parameters of cucumber. The highest rate of $150 \mathrm{~kg} \mathrm{~N}$ in the combination result to higher vegetative growth than fruit yield. The application of $50 \mathrm{~kg} \mathrm{~N}, 50$ $\mathrm{Kg} \mathrm{P}_{2} \mathrm{O}_{5}$ and $75 \mathrm{~kg} \mathrm{~K} 2 \mathrm{O}$ is considered optimal for cucumber production in the study area.

\section{References}

Agboola, S. A., Solubo, R. A, and Fayemi, A. A. (1975). Nutritional requirements of Tomatoes (Lycopersicon esculentum) in S.W.Nigeria.II. Foliar Analysis for assessing N.P.K requirements, Experimental Agriculture, $11 \mathrm{pp} 137-143.10 .1011 / 500144797000658 \mathrm{X}$.

Akinrinde, E.A (2006). Strategies for improving crops use efficiency of fertilizer nutrients. In: Sustainable Agricultural Systems. Pakistan Journal of Nutrition 5(2):185-193

Brady, N. C. and Weil, R. R. (2005). The nature and properties of soil. $13^{\text {th }}$ edn. Macmillan publishing Co. Newyork.

Burkill, H.M (1985). The useful plants of the West Tropical Africa. Vol. 1. Royal Botanical Garden, Kew, UK. $960 \mathrm{pp}$.

Ekwu, L.G., Eselebe, H.O. and Okporie, E.O (2000). Vegetative growth and yield response of cucumber to varying levels of Nitrogen and Phosphorus fertilizer in Southern Nigeria. Conference Proceedings of the Horticultural Society of Nigeria. 2000. Pp. 117-120

Esawy M., Nasser A., Paul R., Nouraya A and Lamyaa A. (2009). Effects of different organic and inorganic fertilizers on Cucumber yield and some soil properties in Egypt. World Journal of Agricultural sciences, 5(4):408-414.

FAO-ISRIC, (1990). Guidelines for profile description. $3^{\text {rd }}$ Edition. Rome

Hamma, I. L., Ibrahim, U., Haruna, M. (2012). Effect of poultry manure on the growth and yield of Cucumber (Cucumis sativum L) in Samaru, Zaria, Nigerian journal of Agricultural food and Environment, 8(1): 94-98

Hector, V., Randall, T. H. and Fukuda, S. (1993) Vegetable Gardening guide. inorganic fertilizer. J. Plant Breeding and Crop Sci. 2(7): 216-220. J.Exp. Botany. 53:773 - 787.

Jasso-Chaverria, C., Hochmuth, G. J., Hochmuth, R. C and Sargent, S.A (2005). Fruit yield, size and color responses of two greenhouse cucumber types to nitrogen fertilization in perlite soil-less culture. HortTechnology 15:565-571

John, N. M., Iren, O. B., Imuk, E. A. (2014). Effect of varying rates of pig manure and NPK (15:15:15) fertilizer on growth, nutrient uptake and yield of fluted pumpkin (Telfairia occidentalis Hook f.). Nig. J. Soil Environ. Res. 12:75 - 81.

Kano, Y., Goto, H., Fukuda, H and Ishimoto, K (2001). Relationship between the occurrence of bitter cucumber (Cucumis sativus L cv. Kagafutokyuri) and total nitrogen, nitrate-N, amino acid-N and protein contents in leaf and peel. J. Jpn. Soc. Hortic. Sci. 70:438-442

Messien, C.M (1988). The tropical vegetables garden- Principles for improvement and increasing production with application to vegetables. MacMillian Publishers, London, UK. Pp. 187-218

Moreno, D.A., Villora, G and Romero, L (2003). Variations in fruit micronutrient contents associated with fertilization of cucumber with micronutrients. Sci. Hortic. 97: 121-127.

Musura, C. and Chitamba, J. (2014). Evaluation of cattle manure application rate on the growth rate and fruit 
yield of cucumber (Cucumis sativus L.) International Resource Journal of Agricultural Science, 4(9):167171

Opara, S. P., Zuofa, K., Isirimah N. O. and Douglas, D. C (2011). Effects of poultry manure supplemented by NPK 15:15:15 fertilizer on cucumber production in Nigeria. African Journal of Biotechnology, 11 (46).10548-10554.

Olatunji, O (2017). Growth and Yield of Cucumber (Cucumis sativa L) As Influenced by Complimentary use of Organic Sources and Mineral Fertilizer in Makurdi, Benue State, Nigeria. International Journal of Agriculture, Environment and Bioresearch Vol. 2 No. 4. 546-555 (on line) www.ijaeb.org

Thoa, D.K. 1998. Cucumber seed Multiplication and characterization A.R.C-AVRDC Research Report. Bangkok, Thailand. http://www.arc_avdrc.org

Udo, E.L., T.O Ibia, J. O. Ogunwale, A.O. Ano and I. Esu (2009). Manual of Soil, Plant and Water Analysis, Sibon books Ltd. Lagos, Pp183.

Table 1: Initial physical and chemical properties of soil of the study area

\begin{tabular}{ll}
\hline Soil Parameters & Value \\
\hline Sand $(\%)$ & 80 \\
Silt $(\%)$ & 5.4 \\
Clay $(\%)$ & 14.6 \\
Textural class & Sandy loam \\
pH $\left(\mathrm{H}_{2} \mathrm{O}\right)$ & 6.3 \\
$\mathrm{pH}(\mathrm{CaCl})$ & 5.93 \\
$\mathrm{O} . \mathrm{C}(\%)$ & 1.48 \\
$\mathrm{O}(\mathrm{M}(\%)$ & 2.55 \\
$\mathrm{~N}(\%)$ & 0.35 \\
$\mathrm{P}\left(\mathrm{mgkg}^{-1}\right)$ & 3.25 \\
$\mathrm{~K}(\mathrm{cmolkg}-1)$ & 0.36 \\
$\mathrm{Ca}\left(\mathrm{cmolkg}^{-1}\right)$ & 2.38 \\
$\mathrm{Mg}\left(\mathrm{cmolkg}^{-1}\right)$ & 2.11 \\
$\mathrm{Na}\left(\mathrm{cmolkg}^{-1}\right)$ & 0.23 \\
E.A $\left(\mathrm{cmolkg}^{-1}\right)$ & 1.67 \\
$\mathrm{CEC}\left(\mathrm{cmolkg}^{-1}\right)$ & 5.08 \\
B.S \% & 67.3 \\
\hline
\end{tabular}

Table 2: Effect of fertilizer treatments on the leaf area and number of cucumber.

\begin{tabular}{crrrrrr}
\hline \multirow{2}{*}{ Treatments } & 4 WAP & 6 WAP & 8 WAP & 4 WAP & 6 WAP & 8 WAP \\
\hline T1 & 87.70 & 167.90 & 225.00 & 7.67 & 21.40 & 32.70 \\
T2 & 110.30 & 226.60 & 295.90 & 9.00 & 40.51 & 46.80 \\
T3 & 115.70 & 229.40 & 319.70 & 9.92 & 34.83 & 49.40 \\
T4 & 108.50 & 193.00 & 246.50 & 8.83 & 24.62 & 43.90 \\
T5 & 111.40 & 149.70 & 236.00 & 9.75 & 37.73 & 41.60 \\
& & & & & & \\
T6 & 133.20 & 199.10 & 240.00 & 7.92 & 22.02 & 31.00 \\
T7 & 104.40 & 210.50 & 295.20 & 9.58 & 41.41 & 50.50 \\
F-LSD $(<0.05)$ & 25.73 & 15.18 & 53.81 & 1.84 & 3.78 & 10.43 \\
\hline
\end{tabular}

Key: T1 (Control) $=0 \mathrm{~kg} \mathrm{~N} / \mathrm{ha}+50 \mathrm{~kg} \mathrm{P}_{2} \mathrm{O}_{5} / \mathrm{ha}+0 \mathrm{~kg} \mathrm{~K} 2 \mathrm{O} / \mathrm{ha} ; \mathrm{T} 2=50 \mathrm{~kg} \mathrm{~N} / \mathrm{ha}+50 \mathrm{~kg} \mathrm{P}_{2} \mathrm{O}_{5} / \mathrm{ha}+50 \mathrm{~kg} \mathrm{~K} 2 \mathrm{O} / \mathrm{ha}$

$\mathrm{T} 3=50 \mathrm{~kg} \mathrm{~N} / \mathrm{ha}+50 \mathrm{~kg} \mathrm{P}_{2} \mathrm{O}_{5} / \mathrm{ha}+75 \mathrm{~kg} \mathrm{~K} \mathrm{O}_{2} / \mathrm{ha}$; T4= 100kg N/ha $+50 \mathrm{~kg} \mathrm{P}_{2} \mathrm{O}_{5} / \mathrm{ha}+50 \mathrm{~kg} \mathrm{~K} / 2 \mathrm{O} / \mathrm{ha}$

$\mathrm{T} 5=100 \mathrm{~kg} \mathrm{~N} / \mathrm{ha}+50 \mathrm{~kg} \mathrm{P}_{2} \mathrm{O}_{5} / \mathrm{ha}+75 \mathrm{~kg} \mathrm{~K}{ }_{2} \mathrm{O} / \mathrm{ha} ; \mathrm{T} 6=150 \mathrm{~kg} \mathrm{~N} / \mathrm{ha}+50 \mathrm{~kg} \mathrm{P}_{2} \mathrm{O}_{5} / \mathrm{ha}+50 \mathrm{kgK}_{2} \mathrm{O} / \mathrm{ha}$;

$\mathrm{T} 7=150 \mathrm{~kg} \mathrm{~N} / \mathrm{ha}+50 \mathrm{~kg} \mathrm{P}_{2} \mathrm{O}_{5} / \mathrm{ha}+75 \mathrm{~kg} \mathrm{~K} 2 \mathrm{O} / \mathrm{ha}$ 
Table 3: Effect of fertilizer treatments on the vine length and yield of cucumber.

\begin{tabular}{|c|c|c|c|c|c|c|c|}
\hline \multirow[b]{2}{*}{ Treatments } & \multicolumn{3}{|c|}{ Vine Length $(\mathrm{cm})$} & \multirow[b]{2}{*}{$\begin{array}{l}\text { Fruit Girth } \\
\qquad(\mathrm{cm})\end{array}$} & \multirow[b]{2}{*}{$\begin{array}{l}\text { Fruit Length } \\
(\mathrm{cm})\end{array}$} & \multirow{2}{*}{$\begin{array}{c}\text { Harvest } \\
\text { Per Plot } \\
\text { (Kg) }\end{array}$} & \multirow{2}{*}{$\begin{array}{l}\text { Fruit } \\
\text { Yield } \\
\text { (t/ha) }\end{array}$} \\
\hline & 4 WAP & $6 \mathrm{WAP}$ & 8 WAP & & & & \\
\hline $\mathrm{T} 1$ & 9.23 & 67.81 & 126.1 & 18.53 & 17.03 & 1.01 & 3.31 \\
\hline $\mathrm{T} 2$ & 11.75 & 78.45 & 142.30 & 19.92 & 18.43 & 1.77 & 1.96 \\
\hline $\mathrm{T} 3$ & 14.02 & 81.05 & 147.30 & 20.07 & 18.77 & 5.37 & 5.96 \\
\hline $\mathrm{T} 4$ & 11.87 & 72.03 & 137.60 & 19.07 & 19.33 & 2.63 & 2.92 \\
\hline $\mathrm{T} 5$ & 13.47 & 82.15 & 115.90 & 19.53 & 17.23 & 3.38 & 3.75 \\
\hline $\mathrm{T} 6$ & 11.05 & 70.57 & 138.30 & 20.80 & 19.97 & 3.45 & 3.83 \\
\hline T7 & 10.27 & 75.29 & 146.00 & 19.13 & 18.10 & 2.62 & 2.91 \\
\hline F-LSD $(<0.05)$ & 2.25 & 5.93 & 33.77 & 1.86 & 3.19 & 4.36 & 4.36 \\
\hline
\end{tabular}

Key:

$\mathrm{T} 1($ Control $)=0 \mathrm{~kg} \mathrm{~N} / \mathrm{ha}+50 \mathrm{~kg} \mathrm{P}_{2} \mathrm{O}_{5} / \mathrm{ha}+0 \mathrm{~kg} \mathrm{~K}{ }_{2} \mathrm{O} / \mathrm{ha} ; \mathrm{T} 2=50 \mathrm{~kg} \mathrm{~N} / \mathrm{ha}+50 \mathrm{~kg} \mathrm{P}_{2} \mathrm{O}_{5} / \mathrm{ha}+50 \mathrm{~kg} \mathrm{~K} 2 \mathrm{O} / \mathrm{ha}$ $\mathrm{T} 3=50 \mathrm{~kg} \mathrm{~N} / \mathrm{ha}+50 \mathrm{~kg} \mathrm{P}_{2} \mathrm{O}_{5} / \mathrm{ha}+75 \mathrm{~kg} \mathrm{~K} 2 \mathrm{O} / \mathrm{ha} ; \mathrm{T} 4=100 \mathrm{~kg} \mathrm{~N} / \mathrm{ha}+50 \mathrm{~kg} \mathrm{P}_{2} \mathrm{O}_{5} / \mathrm{ha}+50 \mathrm{~kg} \mathrm{~K} 2 \mathrm{O} / \mathrm{ha}$ $\mathrm{T} 5=100 \mathrm{~kg} \mathrm{~N} / \mathrm{ha}+50 \mathrm{~kg} \mathrm{P}_{2} \mathrm{O}_{5} / \mathrm{ha}+75 \mathrm{~kg} \mathrm{~K}{ }_{2} \mathrm{O} / \mathrm{ha} ; \mathrm{T} 6=150 \mathrm{~kg} \mathrm{~N} / \mathrm{ha}+50 \mathrm{~kg} \mathrm{P}_{2} \mathrm{O}_{5} / \mathrm{ha}+50 \mathrm{~kg} \mathrm{~K} 2 \mathrm{O} / \mathrm{ha}$; $\mathrm{T} 7=150 \mathrm{~kg} \mathrm{~N} / \mathrm{ha}+50 \mathrm{~kg} \mathrm{P}_{2} \mathrm{O}_{5} / \mathrm{ha}+75 \mathrm{~kg} \mathrm{~K}_{2} \mathrm{O} / \mathrm{ha}$ 